\title{
Effect of Polyamines and NAA Application on Quality and Shelf Life of Mango (Mangifera indica L.) cv. Kesar
}

\author{
Akula Venu ${ }^{1 *}$ and M.V. Ramdevputra ${ }^{2}$ \\ ${ }^{1}$ Department of Horticulture, Junagadh Agricultural University, Junagadh, India \\ ${ }^{2}$ Poly. In Agriculture, Junagadh Agricultural University, Dhari, Amrelli, India \\ *Corresponding author
}

\section{A B S T R A C T}

\begin{tabular}{|l|}
\hline Ke y w o r d s \\
Mango, Polyamines, \\
NAA, Quality and shelf \\
life
\end{tabular}

A study was conduct to investigate the effect of polyamines and NAA on quality and shelf life attributes like, TSS $\left(\right.$ Brix $\left.^{0}\right)$, Ascorbic acid (\%), Acidity (\%), Reducing sugars (\%), Total sugars $\%$ and physiological weight loss (\%), Days to ripening, shelf life (\%), Fruit spoilage (\%) in 15 years old trees of mango cv. Kesar, under Junagadh Agricultural University, Junagadh, saurastra region of Gujarat during 2015-16 and 2016-17. Results indicated that Putrescine $150 \mathrm{ppm}$ reduced TSS (15.60 Brix ${ }^{0}$ ), Ascorbic acid (17.85\%), Reducing sugars $(5.15 \%)$, Total sugars $(14.55 \%)$ and maximum acidity $(0.37 \%)$, as well as reduced physiological weight loss (13.06\%), Days to ripening (16.68), shelf life $(20.73 \%)$, fruit spoilage $(8.71 \%)$ in treated trees over non-treated trees at full bloom stage after post-harvest. Our results suggested that effect of polyamines on mango cv. Kesar to increased quality and shelf life parameters.

\section{Introduction}

Mango (Mangifera indica. L.) belongs to the family Anacardiceae, originated from indoburma region. Owing to excellent flavour, attractive colour, delicious taste and high nutritive value, this prized fruit has occupied premier position in our country and also in the international market.

The fruit is intimately associated with the history of Indian Agriculture and civilization and enjoys a royal status in country when compared to the other growing places. No one will have a difference of opinion about the status given to mango as 'King of Fruits' due to its captivating flavour, irresistible taste and sweetness. Its production has been increasing since independence, contributing $20.7 \%$ of the total fruit production of India. Uttar Pradesh, Andhra Pradesh, Karnataka, Telangana, Maharashtra, Gujarat, Tamil Nadu and Bihar together contribute for about $82 \%$ of the total production in India (Anon., 2014). The important cultivars commercially grown under Gujarat are Kesar, Alphanso, rajapuri, Totapuri, jamadar, vashibadami, Dashehari, langra, Mulgoa, Pairi, and Neelum. Kesar variety grown commercially in Gujarat and it is generally regular bearer, high yielder, early mid-season and adaptable to wide range of soil and climatic conditions with attractive flesh colour, fruit size, excellent sugar: acid blend, good keeping quality and gained wide 
spread among consumers in India as well as in abroad (Arogba, 1999).

Exogenous application of polyamines may improve fruit set, retention and extend the storage life of mango fruits by inhibiting ethylene production (Malik and Singh, 2006). Recent studies of Malik and Singh (2003) revealed that PAs applications generally improved fruit retention and yield in mango depending upon the type and concentration of PAs and phenological stage of application. Spray of SPM prior to anthesis and PUT at full bloom was found more effective in increasing final fruit retention in 'Dashehari' and 'Langra' mango respectively (Singh and Singh, 1995).

Increase in fruit size and levels of endogenous PAs in apples have been associated with exogenous application of PAs which indicated that lower level of these compounds could act as growth limiting factors (Biasi et al., 1988). Exogenous application of polyamines have been demonstrated to influence yield, shelf life and quality of various fruit crops such as apple (Kramer et al., 1989), strawberry (Ponappa et al., 1993), plum (Ren et al., 1995), peaches (Martinez- Romero et al., 2000) and mango (Purwoko et al., 1998).

The role of NAA in the control of vegetative and reproductive development has been the subject of studies of several workers. These substances appear to have different effect at different concentrations (Shinde et al., 2002). The promotion of floral initiation and control of fruit drop are well established by these substances. They also improve size and quality of fruits in mango and other crops (Rani and Brahmachari, 2004).

\section{Materials and Methods}

The experiment was carried out at Fruit Research Station, Sakkarbaugh Farm and
Department of Horticulture, College of Agriculture, Junagadh Agricultural University, Junagadh during 2015-16 and 2016-17. Junagadh is situated at $21.5^{\circ} \mathrm{N}$ latitude and $70.5^{\circ} \mathrm{E}$ longitudes with an altitude of 60 meters above the mean sea level on the western side at the foot hills of the mount 'Girnar'. The present study was conducted on fifteen years old plants of mango cultivar 'Mango'. All the plants selected were uniform in growth and size which planted at the distance of $10 \mathrm{~m} \times 10 \mathrm{~m}$ and were subjected to uniform application of cultural practices like weeding, irrigation, manures, fertilizers and plant protection measures etc.

The polyamines and NAA was used for the present investigation and supplied through Department of Horticulture, Junagadh Agricultural University. The experiment was laid out in Randomized Block Design with ten treatments and three replications. The experiment comprising of ten treatments involving: $\mathrm{T}_{1}-$ Spermine $2 \mathrm{ppm} ; \mathrm{T}_{2}-$ spermine $3 \mathrm{ppm} ; \mathrm{T}_{3}$ - Spermine $4 \mathrm{ppm} ; \mathrm{T}_{4}-$ Putrescine 100 ppm; $\mathrm{T}_{5}$ - Putrescine 150 ppm; $\mathrm{T}_{6}$ - Putrescine $200 \mathrm{ppm} ; \mathrm{T}_{7}-\mathrm{NAA} 20 \mathrm{ppm}$; $\mathrm{T}_{8}$ - NAA $30 \mathrm{ppm}$; $\mathrm{T}_{9}$ - NAA $40 \mathrm{ppm} ; \mathrm{T}_{10}-$ Control (No spray). One spray was done at the full bloom stage of mango cv. Kesar.

\section{Results and Discussion}

\section{Physico-chemical parameters}

Fruit quality characters like total soluble solids $\left({ }^{0}\right.$ Brix), sugars (reducing and total sugars) $(\%)$, titrable acidity (\%) and ascorbic acid (mg/100g) were significantly influenced by foliar spray of different polyamines on mango cv. Kesar. Putrescine $150 \mathrm{ppm}$ was found to be minimum total soluble solids ( ${ }^{0}$ Brix), sugars (reducing and total sugars \%) and maximum acidity (\%). Whereas, highest ascorbic acid $(\mathrm{mg} / 100 \mathrm{~g})$ were recorded in putrescine $150 \mathrm{ppm}$ treatment (Table 1). 
Table.1 Effect of polyamines and NAA application on quality of mango (Mangifera indica L.) cv. Kesar

\begin{tabular}{|c|c|c|c|c|c|c|c|c|c|c|}
\hline \multirow[t]{2}{*}{ Treatments } & \multicolumn{2}{|c|}{ TSS $\left(\right.$ Brix $\left.^{0}\right)$} & \multicolumn{2}{|c|}{ Ascorbic acid\% } & \multicolumn{2}{|c|}{ Acidity \% } & \multicolumn{2}{|c|}{ Reducing sugars\% } & \multicolumn{2}{|c|}{ Total sugars \% } \\
\hline & 2016 & 2017 & 2016 & 2017 & 2016 & 2017 & 2016 & 2017 & 2016 & 2017 \\
\hline$T_{1}$ & 17.30 & 17.36 & 16.62 & 16.67 & 0.34 & 0.34 & 5.44 & 5.51 & 15.57 & 15.62 \\
\hline$\overline{T_{2}}$ & 16.75 & 16.80 & 17.27 & 17.31 & 0.35 & 0.36 & 5.63 & 5.69 & 15.26 & 15.31 \\
\hline $\mathbf{T}_{3}$ & 16.71 & 16.75 & 16.50 & 16.53 & 0.34 & 0.34 & 5.85 & 5.89 & 15.19 & 15.36 \\
\hline$\overline{T_{4}}$ & 17.60 & 17.66 & 17.10 & 17.13 & 0.35 & 0.35 & 5.25 & 5.30 & 14.86 & 15.25 \\
\hline$T_{5}$ & 15.57 & 15.60 & 17.89 & 17.85 & 0.37 & 0.37 & 5.07 & 5.15 & 14.48 & 14.55 \\
\hline$T_{6}$ & 17.44 & 17.49 & 16.79 & 16.82 & 0.36 & 0.36 & 5.38 & 5.41 & 14.85 & 14.89 \\
\hline$T_{7}$ & 17.66 & 17.76 & 16.70 & 16.73 & 0.32 & 0.32 & 6.03 & 6.07 & 15.61 & 15.64 \\
\hline $\mathrm{T}_{8}$ & 18.22 & 18.29 & 16.62 & 16.44 & 0.31 & 0.32 & 6.07 & 6.11 & 16.14 & 16.21 \\
\hline$T_{9}$ & 18.93 & 19.01 & 15.93 & 15.99 & 0.30 & 0.31 & 6.14 & 6.18 & 16.27 & 16.30 \\
\hline$T_{10}$ & 19.53 & 19.71 & 15.57 & 15.60 & 0.29 & 0.30 & 6.23 & 6.26 & 16.33 & 16.38 \\
\hline S.Em. \pm & 0.73 & 0.71 & 0.35 & 0.40 & 0.01 & 0.01 & 0.19 & 0.18 & 0.41 & 0.40 \\
\hline
\end{tabular}

Table.2 Effect of polyamines and NAA application on shelf life of mango (Mangifera indica L.) cv. Kesar

\begin{tabular}{|c|c|c|c|c|c|c|c|c|}
\hline \multirow{2}{*}{ Treatments } & \multicolumn{2}{|c|}{ PWL\% } & \multicolumn{2}{c|}{ Days to ripening } & \multicolumn{2}{c|}{ Shelf life \% } & \multicolumn{2}{c|}{ Fruit spoilage (\%) } \\
\hline & $\mathbf{2 0 1 6}$ & $\mathbf{2 0 1 7}$ & $\mathbf{2 0 1 6}$ & $\mathbf{2 0 1 7}$ & $\mathbf{2 0 1 6}$ & $\mathbf{2 0 1 7}$ & $\mathbf{2 0 1 6}$ & $\mathbf{2 0 1 7}$ \\
\hline $\mathrm{T}_{1}$ & 14.12 & 14.21 & 14.48 & 14.69 & 18.02 & 18.75 & 12.04 & 12.49 \\
\hline $\mathrm{T}_{2}$ & 13.16 & 13.25 & 15.69 & 15.90 & 19.60 & 19.94 & 10.21 & 10.54 \\
\hline $\mathrm{T}_{3}$ & 13.83 & 13.91 & 13.81 & 14.02 & 17.93 & 18.05 & 13.21 & 13.50 \\
\hline $\mathrm{T}_{4}$ & 13.63 & 13.73 & 15.28 & 15.48 & 19.03 & 19.26 & 14.57 & 14.69 \\
\hline $\mathrm{T}_{5}$ & 13.04 & 13.06 & 16.47 & 16.68 & 20.53 & 20.73 & 8.57 & 8.71 \\
\hline $\mathrm{T}_{6}$ & 13.45 & 13.50 & 14.52 & 14.73 & 18.32 & 18.57 & 13.31 & 13.55 \\
\hline $\mathrm{T}_{7}$ & 14.89 & 14.97 & 14.35 & 14.56 & 18.11 & 18.31 & 18.55 & 18.88 \\
\hline $\mathrm{T}_{8}$ & 15.08 & 15.15 & 13.34 & 13.55 & 17.07 & 17.37 & 20.12 & 20.46 \\
\hline $\mathrm{T}_{9}$ & 15.18 & 15.34 & 12.47 & 12.68 & 16.51 & 16.66 & 21.33 & 21.48 \\
\hline $\mathrm{T}_{10}$ & 15.90 & 16.01 & 11.39 & 11.61 & 15.14 & 15.42 & 23.04 & 23.63 \\
\hline \hline $\mathrm{S}_{\mathbf{E}} \boldsymbol{E m}_{.} \pm$ & 0.45 & 0.40 & 0.33 & 0.30 & 0.98 & 0.98 & 0.96 & 0.81 \\
\hline
\end{tabular}

Regarding non-reducing sugars, no positive effect was observed with the spray of either of the polyamines.

Putrescine might retard chlorophyll destruction and/or increased their biosynthesis.

Polyamine may retard senescence by altering the stability and permeability of membranes, by protecting and preventing chloroplasts from senescing and therefore retarding chlorophyll loss (Gonzalez-Aguialar et al., 1997). Diamine aminotransferase transfers the amino group of puttrescine to a-oxoglutaric acid, the precursor of chlorophyll (Askar and Treptow, 1986). Promotive effects of polyamines on photosynthetic pigments were also observed in mulberry (Das et al., 2002), cucumber (He et al., 2002) and common bean (Nassar et al., 2003). Thus, beneficial effect of foliar application of putrescine in enhancing fruit quality is notably due to the bio regulatory effect on enzymatic activity and translocation processes from leaves to fruits, linking or converting to other plant metabolites (Serafini-Fracassini and Del Duca, 2008). 
The findings of Malik and Singh (2006) in mango, Marzouk and Kassem (2011) in grape, Kassem et al., (2011) in ber, Abd ElMigeed et al., (2013) in date palm and Ali et al., (2010) in apricot are in agreement with the present investigation.

\section{Physiological loss in weight (\%)}

The loss in weight of fruit increased with increasing storage period irrespective of any treatment. However, this increase was at reduced rate in all the treated fruits as compared to control.

The results of the present investigation indicated that physiological loss in weight was significantly influenced by the application of polyamines.

The minimum loss in weight starting from the day of storage up to the $16^{\text {th }}$ day occurred consistently in fruits treated with putrescine $150 \mathrm{ppm}$. Similarly, the maximum loss in weight was observed in untreated fruits during the entire storage period.

The reduced loss in weight of fruit was more evident in fruit treated with putrescine, it might be due to comparatively lower rates of respiration and increased fruit firmness (Valero et al., 2002). The findings of Mirdehghan et al., (2013a) in pistachio nut, Malik et al., (2006) in mango are in confirmation with the present investigation.

\section{Days to ripening}

The maximum days to ripening (16.47, 16.68 and 16.58 days) were recorded at treatment $\mathrm{T}_{5}$ (putrescine $150 \mathrm{ppm}$.) as compared to other treatments and the minimum days to ripening $(11.39,11.61$ and 11.50 days) were recorded in treatment $\mathrm{T}_{10}$ (control) during the both years and in pooled respectively.
Application of putrescine $150 \mathrm{ppm}$ could be due to delayed changes associated with the senescence such as ethylene production, browning, peroxide level and cell leakage (Jiang and Chen, 1995), preventing fungal infection (Mirdehghan et al., 2013a) and retardation of fruit softening due to the inhibition of polygalacturonase activities, presumeably through binding to pectic substances (Kramer et al., 1989).

\section{Shelf life (days)}

The significant improvement was observed in shelf life of mango fruits by the application polyamines. The maximum shelf life was recorded in fruits treated with putrescine 150 ppm and the minimum shelf life was observed in fruits harvested from untreated trees (Table 2).

The probable reasons for increased shelf life by application of putrescine $150 \mathrm{ppm}$ could be due to delayed changes associated with the senescence such as ethylene production, browning, peroxide level and cell leakage (Jiang and Chen, 1995), preventing fungal infection (Mirdehghan et al., 2013a) and retardation of fruit softening due to the inhibition of polygalacturonase activities, presumeably through binding to pectic substances (Kramer et al., 1989).

Similar findings were also observed by Malik et al., (2006) in mango, Khan and Singh (2008) in plum, Mirdehghan et al., (2013a) in pistachio nut and Mirdehghan et al., (2013b) in grape.

\section{Spoilage (\%)}

Fruit spoilage was significantly influenced by the application polyamines. The minimum spoilage was reported in fruits receiving putrescine $150 \mathrm{ppm}$. Whereas, the maximum spoilage was observed in fruits from untreated trees. 
Reduced spoilage can be attributed to a decrease in the microbial activity of fruits (Mirdehghan et al., 2013a). Polyamines conjugated to phenolic compounds and hydroxycinamic acid amides have been shown to accumulate in cells in interactions between plants and a variety of pathogens (Walters, 2003). Thus, putrescine treated fruits had less fungal infection than untreated ones.

Similar findings were also observed by Mirdehghan et al., (2013a) in pistachio nut and Mirdehghan et al., (2013b) in grape.

\section{References}

Abd El-Migeed, M. M. M., Mostafa, E. A. M., Ashour, N. E., Hassan, H. S. A., Mohamed, D. M. and Saleh, M. M. S. (2013). Effect of potassium and polyamine sprays on fruit set, fruit retention, yield and fruit quality of 'Amhat' date palm. Int. J. Agri. Res., 8(2): 77-86.

Ali, E. A. M., Sarrwy, S. M. A. and Hassan, H. S. A. (2010). Improving 'Canino' apricot trees productivity by foliar spraying with polyamines. J. Appl. Sci. Res., 6(9): 1359-1365.

Anonymous (2014). Horticultural Database. $N H B$, Ministry of Horticulture, New Delhi.

Arogba, S. S. (1999). The performance of processed mango karnel flour in a model food system. Bioresourses Technology, 70 (2): 277-281.

Askar, A. and Treptow, H. (1986). Bio-gene amine in lebensmittlen a Veleg Eugen ulmer. Stuttgart.

Biasi, R., Bagni, N. and Costa, G. (1988). Endogenous polyamines in apple and their relationship to fruit set and fruit growth. Physiol. Plant, 73: 201-205.

Das, C., Sengupta, T., Chattopadhyay, S., Setua, M., Das, N. K. and Saratchandra,
B. (2002). Involvement of kinetin and spermidine in controlling salinity stress in mulberry. Physiol. Plant, 24: 53-57.

Gonzalez-Aguilar, G. A., Zacarias, L., Mulas, M. and Lafuente, M. T. (1997). Temperature and duration of water dips influence chilling injury, decay and polyamine content in Fortune mandarins. Postharvest. Biol. Technol., 12: 61-69.

He, L., Nada, K. and Tachibana, S. (2002). Effects of spermidine pretreatment through the roots on growth and photosynthesis of chilled cucumber plants. J. Jpn. Soc. Hort. Sci., 71: 490498.

Jiang, Y. M. and Chen, F. (1995). A study on polyamine change and browning of fruit during cold storage of litchi. Postharvest Biol. Technol., 5: 245-250.

Kassem, H. A., Al-Obeed, R. S., Ahmed, M. A. and Omar, A. K. H. (2011). Productivity, fruit quality and profitability of jujube trees improvement by pre harvest application of agro- chemicals. Middle-East J. Sci. Res., 9(5): 628-637.

Khan, A. S. and Singh, Z. (2008). Influence of pre and postharvest applications of putrescine on ethylene production, storage life and quality of plum (Prunus salicina L. cv. 'Angelino'). Acta. Hort., 768: 125-133.

Kramer, G. F., Wang, C. Y. and Conway, W. S. (1989). Correlation of reduced softening and increased polyamine levels during low oxygen storage of 'Mclntosh' apples. J. Amer. Soc. Hort. Sci., 114: 942-946.

Malik, A. U and Singh, Z. (2003). Abscission of mango fruitlets as influenced by biosynthesis of polyamines. J. Horti. Sci. Biotech., 78 (5): 721-727.

Malik, A. U and Singh, Z. (2006). Improved fruit retention, yield and fruit quality in 
mango with exogenous application of polyamines. Sci. Horti., 110: 167-174.

Malik, A. U., Singh, Z. and Tan, S. C. (2006). Exogenous application of polyamines improve shelf life and fruit quality of mango. Acta. Hort. 699.

Martinez-Romero, D., Valero, D., Serrano, M., Burlo, F., Carbonell, A, Burgos L. and Riquelme, F. (2000). Exogenous polyamines and gibberellic acid effects on peach (Prunus persica L.) storability improvement. J. Food Sci., 65: 288-294.

Marzouk, H. A. and Kassem, H. A. (2011). Improving yield, quality and shelf life of 'Thomson Seedless' grape vine by pre harvest foliar applications. Sci. Hort., 130: 425-430.

Mirdehghan, S. H., Khanamani, Z. and Shamshiri, M. H. (2013a). Preharvest foliar application of putrescine on postharvest quality of fresh pistachio nut. Acta. Hort., 1012: 299-304.

Mirdehghan, S. H., Rahimi, S. and Esmaeilizadeh, M. (2013b). Improving the postharvest characteristics of table grape by pre harvest application of polyamines. Acta. Hort., 1012: 293-298.

Nassar, A. H., El-Tarabily, K. A. and Sivasithamparam, K. (2003). Growth promotion of bean by a polyamine producing isolate of Streptomyces griseoluteus. Plant Growth Regul., 40: 97-106.

Ponappa T., Scheerens, J. C. and Miller, A. R. (1993). Vaccum infiltration of polyamines increases firmness of strawberry slices under various storage conditions. J. Food Sci., 58: 361-364.

Purwoko, B. S., Kesmayanti, N.; Susanto, S and Nasution, M. Z. (1998). Effect of polyamines on quality changes in papaya and mango fruits. Acta Horti., 464.

Rani Ruby and Brahmachari, V. S. (2004). Effect of growth substances and calcium compounds on fruit retention, growth and yield of Amrapali mango. Orissa J. Hort., 32(1): 15-18.

Ren, X. L., Ma, F. W. and Wang, F. (1995). Effect of spermidine on ethylene and respiration of plum. Pl. Physio. Comm., 31: 400-411.

Serafini-Fracassini, D. and Del Duca, S. (2008). Transglutaminases: wide spread cross linking enzymes in plants. Ann. Bot., 102: 145-152.

Shinde, A. K., Dalvi, M., Godse, S., Patil, B. and Pujari, K., (2002). Evaluation of chemical and growth regulatory for post-harvest treatment of fruits in Alphonso mango. VII Inter. Mango Sym., Recife, Brazil, p.77.

Singh, Z., and Singh, L. (1995). Increased fruit set and retention in mango with exogenous application of polyamines. $J$. Hort. Sci., 70: 271-277.

Valero, D., Martinez, R. D. and Serrano, M. (2002). The role of polymines in the improvement of the shelf life of fruits. Trends Food Sci. Tech., 13: 228-234.

Walters, D. R. (2003). Polyamines and plant disease. Phytochem., 64: 97-107

\section{How to cite this article:}

Akula Venu and Ramdevputra, M.V. 2018. Effect of Polyamines and NAA Application on Quality and Shelf Life of Mango (Mangifera indica L.) cv. Kesar. Int.J.Curr.Microbiol.App.Sci. 7(05): 2906-2911. doi: https://doi.org/10.20546/ijcmas.2018.705.339 